\title{
2-es típusú diabetesesek és nem cukorbetegek területen szerzett, belgyógyászati osztályos felvételt igénylő bakteriális infekcióinak klinikai összehasonlítása
}

\author{
Barkai László József dr. ${ }^{1}$ - Sipter Emese dr. ${ }^{1,2}$ - Csuka Dorottya dr. ${ }^{1}$ \\ Baló Tímea dr. ${ }^{1}$ - Nébenführer Zsuzsa dr. ${ }^{1}$ - Máthé András dr. ${ }^{3}$ \\ Karádi István dr. ${ }^{1}$ - Pánczél Pál dr. ${ }^{1}$ \\ Prohászka Zoltán dr. ${ }^{1}$. Hosszúfalusi Nóra dr. ${ }^{1}$ \\ ${ }^{1}$ Semmelweis Egyetem, Általános Orvostudományi Kar, III. Belgyógyászati Klinika, Budapest \\ ${ }^{2}$ Magyar Honvédség Egészségügyi Központ, Sürgősségi Centrum, Budapest \\ ${ }^{3}$ Pest Megyei Flór Ferenc Kórház, Kistarcsa
}

Bevezetés: Korábban azt gondoltuk, hogy a bakteriális fertőzések cukorbetegségben gyakoribbak, súlyosabbak, nagyobb halálozással járnak, mint a nem cukorbetegek körében. Az újabb megfigyelések azonban ellentmondásosak. Célkitüzés: Prospektív, obszervációs vizsgálatunk célja az volt, hogy összehasonlítsuk 2-es típusú cukorbetegek (T2DM) és nem cukorbetegek $(\mathrm{K})$ területen szerzett, belgyógyászati osztályos felvételt igénylő bakteriális infekcióit: 1) lokalizáció, 2) kórokozóspektrum, 3 ) 3 hónapos halálozás alapján.

Módszer: Vizsgálatunkba konszekutív módon vontuk be a betegeket (T2DM: $\mathrm{n}=205, \mathrm{~K}: \mathrm{n}=202$ ). Jellemeztük a két csoport infekcióit, klinikai paramétereit, mortalitásukat, és összevetettük azokat a nemzetközi adatokkal.

Eredmények: A glikémiát jellemző paramétereket és a BMI-t kivéve nem volt különbség a két csoport klinikai jellemzőiben. T2DM-ben a bőr- és lágyrész-fertőzés (37,1\%), a K csoportban a légúti infekció volt a leggyakoribb (37,1\%), melyeket a húgyúti infekciók követték $(31,2 \% ; 31,7 \%)$. A bőr- és lágyrész-infekció előfordulása T2DM-ben vizsgálatunkban meghaladja a nemzetközi adatokat (37,1\% vs. 16\%). T2DM-ben, a K csoporthoz viszonyítva, ezen infekciótípusban többször találtuk Gram-pozitív és Gram-negatív kórokozók együttes jelenlétét $(23 / 76$ vs. 5/46, p = $0,0149)$, a húgyúti fertőzésekben polimikrobás infekciókat (34,0\% vs. 15,1\%,p=0,0335). Mortalitásbeli különbséget nem találtunk a két csoport között. T2DM-ben a bőr- és lágyrész-fertőzések, a nem cukorbetegeknél a légúti infekciók okozták a legtöbb halált.

Következtetés: Területen szerzett, bakteriális infekció miatt belgyógyászati osztályra került 2-es típusú cukorbetegeinknél a nemzetközi adatokhoz képest nagyobb arányban találtunk bőr- és lágyrész-fertőzést; kórokozóként a leggyakrabban Gram-pozitív és Gram-negatív baktériumok együttes jelenlétét tudtuk kimutatni. Összességében nem találtunk különbséget a T2DM- és a nem cukorbeteg csoport között a 3 hónapos halálozásban. Eredményeink felhívják a figyelmet a primer prevenció fontosságára és hazai elégtelenségére a bőr- és lágyrész-fertőzés megelőzésében 2 -es típusú cukorbetegségben.

Orv Hetil. 2019; 160(41): 1623-1632.

Kulcsszavak: 2-es típusú cukorbetegség, bőr-és lágyrész-fertőzések, bakteriális fertőzések, területen szerzett fertőzések, halálozás

\section{Community-acquired bacterial infections among type 2 diabetic and non- diabetic patients hospitalized on a general medical ward: a clinical comparison}

Introduction: Previous data showed bacterial infections among diabetic patients to be more serious and frequent, with higher mortality rates in comparison with non-diabetics. Recent investigations, however, are contradictory. Aim: The goal of our prospective, observational study was to compare patients hospitalized on a general medical ward due to community-acquired bacterial infections with type 2 diabetes mellitus (T2DM) to those of non-diabetics (K) by 1 ) infection localization, 2) spectrum of pathogens, 3 ) three-month mortality rates. 
Method: Patients were consecutively involved (T2DM: $\mathrm{n}=205, \mathrm{~K}: \mathrm{n}=202$ ). We characterized the infections, clinical parameters, mortalities of the two groups, and matched them to international data.

Results: No difference regarding clinical details of the groups were found except for glycemic parameters and BMI. In the T2DM group the skin- and soft tissue- (37.1\%), in the K patients respiratory infections (37.1\%) were the most common, followed by urinary ones $(31.2 \%$ and $31.7 \%$, respectively). Skin- and soft tissue infection incidence among T2DM subjects were higher compared to international results $(37.1 \%$ vs. $16 \%)$. Co-presence of Gram positive and Gram negative bacteria in the skin- and soft tissue infections $(23 / 76$ vs. $5 / 46, \mathrm{p}=0.0149)$, and polymicrobial origin in the urinary tract infections $(34.0 \%$ vs. $15.1 \%, \mathrm{p}=0.0335)$ were found to be more frequent in $\mathrm{T} 2 \mathrm{DM}$ than in $\mathrm{K}$. No difference regarding mortality rates were detected. In T2DM the skin- and soft tissue while in the K group the respiratory infections had the most death counts.

Conclusions: We found higher rates of skin- and soft tissue infections among T2DM patients hospitalized on a general medical ward compared to international data. In total we did not find difference regarding three-month mortality between the groups. Our results highlight the importance of primary prevention and shows its inadequacy concerning skin and soft tissue infections among type 2 diabetics in Hungary.

Keywords: type 2 diabetes mellitus, skin and soft tissue infections, bacterial infections, community-acquired infection, mortality

Barkai LJ, Sipter E, Csuka D, Baló T, Nébenführer Zs, Máthé A, Karádi I, Pánczél P, Prohászka Z, Hosszúfalusi N. [Community-acquired bacterial infections among type 2 diabetic and non-diabetic patients hospitalized on a general medical ward: a clinical comparison]. Orv Hetil. 2019; 160(41): 1623-1632.

(Beérkezett: 2019. április 18.; elfogadva: 2019. május 24.)

\section{Rövidítések}

AGE = (advanced glycation end products) kései glikációs végtermékek; BAL $=($ bronchoalveolaris lavage $)$ tüdőöblítés; BMI $=($ body mass index $)$ testtömegindex $; \mathrm{CCI}=\left(\right.$ Charlson $\mathrm{Co}^{-}$ morbidity Index) Charlson-féle komorbiditási index; COPD = (chronic obstructive pulmonary disease) krónikus obstruktív tüdőbetegség; CRP = C-reaktív protein; $\mathrm{EK}=$ Egészségügyi Központ; $\mathrm{HbA}_{\mathrm{lc}}=$ hemoglobin- $\mathrm{A}_{\mathrm{lc}} ; \mathrm{HPLC}=$ (high-performance liquid chromatography) nagy hatékonyságú folyadékkromatográfia; hsCRP $=($ high-sensitivity $\mathrm{C}$-reactive protein $)$ nagy szenzitivitású C-reaktív protein; $\mathrm{MH}=$ Magyar Honvéd ség; $\mathrm{OAD}=$ orális antidiabetikum; SIRS = (systemic inflammatory response syndrome) szisztémás gyulladásos reakció szindróma; SSTI $=$ (skin- and soft tissue infection) bör- és lágyrész-fertôzés; T2DM = (type 2 diabetes mellitus) 2 -es típusú cukorbetegség; TUKEB = Tudományos és Kutatásetikai Bizottság; $\mathrm{WHO}=$ (World Health Organization) Egészségügyi Világszervezet

Korábbi adatok arra utaltak, hogy a bakteriális fertőzések gyakrabban fordulnak elő, súlyosabbak, nagyobb mortalitással járnak cukorbetegségben, mint a nem cukorbetegek körében [1]. Újabb megfigyelések alapján az ezzel kapcsolatos epidemiológiai vizsgálatok eredményei ellentmondásosak, és nagyban függnek az adott vizsgálat felépítésétől [2].

Régóta ismert, hogy bizonyos fertőzések gyakoribbak cukorbetegségben. Avicenna már kb. 1000 évvel ezelőtt kapcsolatot talált a diabetes és a tuberkulózis között [3], de szoros összefüggés ismert malignus otitis externa [4], emphysemás pyelonephritis [5], emphysemás cholecystitis [6], Klebsiella baktérium okozta májtályog [7], vala- mint melioidosis esetén is [8]. Ezek a kórképek bár meglehetősen ritkák, a legtöbbjük fóleg csak cukorbetegekben jelentkezik. Ugyanakkor diabetesben is nem a fentiekkel, hanem elsősorban az átlagpopulációban előforduló infekciókkal találkozunk. Egy több mint 500000 cukorbeteg és ugyanennyi nem cukorbeteg adatait feldolgozó kanadai tanulmány - a vizsgált egyéves követési periódus alatt - diabetesben magasabb relatív infekciós kockázatot talált az alsó légúti $(1,18)$, a húgyúti $(1,39)$ és a bőr- és lágyrész-fertőzések $(1,81)$ előfordulására vonatkozóan, mint a nem diabeteses populációban [9]. Mindezt később egy dán prospektív vizsgálat is megerősítette (esélyhányadosok alsó légúti, húgyúti és bőr- és lágyrész-infekciókra: 1,32, 1,24, 1,33) [10]. Noha a relatív kockázatok eltérnek a különböző tanulmányokban, a legtöbb kutatás kiemeli, hogy a cukorbetegek fogékonyabbak a bőrés lágyrész-fertőzésekre $[11,12]$. A cukorbetegek nagyobb fertőzési kockázatának oka nem kellően tisztázott. Egyesek a gyakoribb orvoshoz fordulást vetették fel, ami torzíthatja az eredményeket [13]. Mások azt sugallják, hogy a különbséget ugyanazon cukorbetegek ismétlődő fertőzései okozzák, és nem az infekció miatt ellátott egyének száma különbözik a két csoport között, adott időintervallum alatt [14].

A fertőzések további klinikai következményei még kevésbé egyértelmúek. Számos vizsgálat pozitív összefüggést talált a diabetes és az infekció okozta mortalitás [9, 12, 15-17], valamint a diabetes és az infekció miatti kórházi tartózkodás között $[11,18]$. Emiatt egyes szerzők az infekciót a diabetes egyik szövődményeként emlegetik [9]. A fentiekkel ellentétben más tanulmányok nem írnak le a halálozást illető különbséget $[19,20]$, sőt van- 
nak, amelyek éppen ellenkezőleg, a cukorbetegek jobb túléléséról számolnak be szepszisben [21]. Az ellentmondásos eredmények hátterében több tényező állhat. Nem minden vizsgálat különíti el például az l-es típusú diabetest a 2-es típusútól [11]. Továbbá a vizsgálatok felépítése, a bevont egyének száma, a betegség súlyossága, az egyes országonként eltérő terápia, valamint a különböző statisztikai elemzések is sok esetben különböznek [2]. A populációs vizsgálatok általában kevésbé kitettek a betegek kiválasztásából adódó torzításnak, ugyanakkor részletesebb információval a klinikai tanulmányok szolgálhatnak. Fontos továbbá megjegyezni, hogy a cukorbetegség számos szövődménnyel járhat, melyeknek a statisztikai elemzés során való korrigálása vitatott [2].

Bizonyos tanulmányok magát a cukorbetegséget az infekció okozta halálozás független rizikófaktoraként említik [16], míg mások a diabeteshez társuló krónikus szövődmények, a glikáció vagy a hyperglykaemia - függetlenül a cukorbetegségtől - jelentőségét hangsúlyozzák [15, 22, 23].

$\mathrm{Az}$ egyes infekciók kimenetelében fontos szerepet játszhat, hogy cukorbetegségben megváltozhat a szervezet immunválasza. A neutrophil granulocyták csökkent kemotaxisát, migrációját, 'killing' mechanizmusát, valamint fokozott adherenciáját már évtizedekkel ezelőtt leírták $[24,25]$. Az adaptív immunválaszt tekintve a fokozott glikációt megváltozott T-lymphocyta-funkcióval és csökkent antitestválasszal hozták összefüggésbe [26, 27]. Munkacsoportunk nemrégiben publikálta a komplementrendszer károsodott múködését 2-es típusú cukorbetegségben, bakteriális infekciók során [28].

Számos adat szól a cukorbetegek infekcióinak eltéró kórokozóspektrumáról, agresszívebb ágensek jelenlétéről. Diabeteses húgyúti infekciókban a patogének között a monopatogénes Escherichia coli-fertőzés kisebb [29], míg a Klebsiella, az Aerococcus és a B csoportú Streptococcus [30], valamint a Proteus és az Enterococcus nagyobb arányban fordul elö, mint a nem cukorbeteg egyének hasonló fertőzéseiben [31]. Cukorbetegségben az E. coli jobban kötődhet az uroepithelialis sejtekhez, azok glikációja miatt $[32,33]$. Egyes közlemények gyakoribb antibiotikum- (ofloxacin- és cefixim-) rezisztenciáról számolnak be, baktériumtípustól függetlenül [34]. Az aszimptomatikus bacteriuria szintén elterjedtebb, emiatt korábban felmerült az antibiotikumkezelés szükségessége, azonban a komplikációkat mindez nem csökkentette. Jelenleg a tünetmentes bacteriuria szürése és kezelése cukorbetegek esetén sem szerepel a terápiás ajánlások között [5, 35]. A légúti fertőzésekkel kapcsolatosan leírták, hogy a Pneumococcus gyakrabban okoz bacteriaemiát, továbbá hogy alsó légúti infekció hátterében olyan kórokozó is állhat, mely nem cukorbetegekben általában ritkán fordul elő (Streptococcus agalactiae) [31]. A lágyrész-infekciókat tekintve a diabeteses láb mára önálló klinikai entitássá vált. Általában polimikrobás fertőzésként jellemezhető, a leginkább gyakori Gram-pozitív aerob kórokozók mellett nagy számban fordulhatnak elő Gram-negatív és anaerob patogének is. Gondolni kell továbbá egyéb multirezisztens törzsekre is [31]. Egy bangladesi vizsgálat a diabeteses és nem diabeteses lábinfekciók kórokozóspektrumát hasonlította össze [36]. Tenyésztési eredményeik szerint mindkét csoportban előfordultak Pseudomonas-, Bacillus-, Enterobacter-, Staphylococcus- és Acinetobacter-törzsek, azonban Enterococcus és Klebsiella csak diabetesben, míg Citrobacter csak cukorbetegség nélkül volt jelen.

A jelenlegi nemzetközi (Egyesült Királyság) és hazai ajánlásokban az infekció nem szerepel önálló diabetesszövődményként, és nem találunk specifikusan eltérő terápiás utasítást diabeteses betegek infekcióira vonatkozóan $[37,38]$.

Prospektív vizsgálatunk célja az volt, hogy összehasonlítsuk 2-es típusú cukorbetegek és nem cukorbetegek területen szerzett, belgyógyászati osztályos felvételt igénylő bakteriális infekcióit az alábbi szempontok alapján: 1) az infekció lokalizációja, 2) kórokozóspektruma, 3 ) kórházon belüli és azt követő 3 hónapos mortalitás. További célunk volt eredményeink összevetése a nemzetközi adatokkal.

\section{Módszer}

\section{Betegek}

Prospektív, obszervációs vizsgálatunkba területen szerzett bakteriális infekció klinikai diagnózisa miatt kórházba utalt és belgyógyászati osztályra felvett betegeket válogattunk be, a 2013. 09. 01. és 2016. 12. 31. közötti időszakban, konszekutív módon. Az ápolási otthonból való beutalás önmagában nem számított kizárási kritériumnak, azonban a felvételt megelőző 3 hónapban történt kórházi tartózkodás igen. Felmérésünk a Semmelweis Egyetem III. Sz. Belgyógyászati Klinikáján, a $\mathrm{MH}$ EK Sürgősségi Centrumban és a Pest Megyei Flór Ferenc Kórházban történt.

A betegeket két csoportra osztottuk a 2-es típusú cukorbetegség WHO-kritériumok [39] szerinti megléte (T2DM) és hiánya $(\mathrm{K})$ alapján. A statisztikai 'power' analízis (erőelemzés) alapján célunk mindkét csoportba 200-200 beteg bevonása volt. Beválasztási kritériumnak számított a minimum 18 éves életkor és a klinikailag igazolt, bakteriális infekció diagnózisa, mely a beteg belgyógyászati osztályos felvételének szükségességét eredményezte. Kizárási kritérium volt bármely hematológiai, onkológiai vagy immunológiai alapbetegség diagnózisa.

\section{Etika}

A vizsgálati protokoll a Tudományos és Kutatásetikai Bizottság (TUKEB 396/2013-31584/2013/EKU) által jóváhagyott. A vizsgálatba bevont résztvevőket előzőleg részletesen tájékoztattuk, majd írásos beleegyezésüket kértük a helsinki deklarációnak megfelelően. 


\section{Adatgyüjtés}

A betegek kórlapjait és orvosi dokumentációját számítógépes rendszerben rögzítettük, és összehasonlítottuk óket a már korábbról meglévő adataikkal. A hiányzó információkat az általuk megadott saját és/vagy legközelebbi hozzátartozó telefonszámán keresztül gyújtöttük be.

Minden, a kutatásban részt vevő esetén regisztráltuk az általános klinikai jellemzőket (kor, nem, vérnyomás, szívfrekvencia, testtömegindex, társbetegségek), a fertőzésre és a hospitalizációra vonatkozó adatokat (az infekció lokalizációja, az antibiotikumkezelés és időtartama, a kórházban töltött napok száma, szepszis megléte, bent fekvési és kórházba kerülést követô 3 hónapos halálozás), a mikrobiológiai tenyésztési eredményt az infekció helyétől függő́en (vizelettenyésztés, sebváladék-tenyésztés, hemokultúra), valamint a laborvizsgálati eredményeket (teljes vérkép, CRP, prokalcitonin, ionok és vesefunkció, májfunkció, véralvadás, lipidek, pajzsmirigyfunkció). A vércukor- és glikációs paramétereket szintén mindkét csoportban meghatároztuk (felvételi vércukorszint, fruktózamin, $\mathrm{HbA}_{\mathrm{lc}}$, AGE: advanced glycation end products - kései glikációs végtermékek). A cukorbetegek esetén rögzítettük betegségük tartamát, a felvételi antidiabetikumterápiát, és megmértük a C-peptid- és Dvitamin-szinteket.

A szepszist a SIRS- (systemic inflammatory response syndrome) kritériumok alapján definiáltuk: 1) testhőmérséklet $>38^{\circ} \mathrm{C}$ vagy $\left.<36{ }^{\circ} \mathrm{C}, 2\right)$ szívfrekvencia $>90$ / perc, 3) légzésszám $>20 /$ perc vagy artériás $\mathrm{PCO}_{2}<32$ $\mathrm{Hgmm}$, 4) fehérvérsejtszám $>12000 / \mathrm{mm}^{3}$ vagy $<4000$ / $\mathrm{mm}^{3}$. Minden beteget a kórházi bent fekvés alatt és után klinikailag követtünk. A társbetegségeket a Charlson Comorbidity Index (CCI) alapján definiáltuk [40]. Hogy összehasonlítható legyen a két csoport komorbiditása, a T2DM-csoport CCI-értékébe a cukorbetegségből adódó pontszámot nem számoltuk bele. A T2DM-csoport kórházon belüli cukoranyagcsere-vezetése napi többszöri praeprandialis vércukormérés alapján, a helyi protokollnak megfelelően történt.

1. táblázat | Klinikai paraméterek felvételkor, belgyógyászati osztályos felvételt igénylő, közösségben szerzett, bakteriális infekciók esetén 2-es típusú diabetes mellitusban és nem diabeteses populációban

\begin{tabular}{|c|c|c|c|}
\hline & 2-es típusú diabeteses $(\mathrm{n}=205)$ & Nem diabeteses $(\mathrm{n}=202)$ & Szignifikancia \\
\hline Férfi/nő arány & $97 / 108$ & $97 / 105$ & NS \\
\hline Életkor - év & $72[64,0-80,0]$ & $73[59,0-82,0]$ & NS \\
\hline Diabetestartam - év & $14,0[6,0-23,8]$ & - & - \\
\hline \multirow[t]{4}{*}{ Diabetesterápia } & $34(16,6 \%)$ & & \multirow{4}{*}{ - } \\
\hline & $86(41,9 \%)$ & & \\
\hline & $\mathrm{OAD}+$ inzulin & & \\
\hline & Csak inzulin & & \\
\hline Felvételi vércukor - mmol/1 & $10,8[7,9-16,0]$ & $6,5[5,8-7,7]$ & $\mathrm{p}<0,0001$ \\
\hline Fruktózamin $-\mu \mathrm{mol} / 1$ & $231,9[205,9-316,8]$ & $193,5[169,7-204,8]$ & $\mathrm{p}<0,0001$ \\
\hline $\mathrm{HbA}_{\mathrm{lc}}-\%$ & $7,5[6,4-8,8]$ & $5,6[5,2-5,9]$ & $\mathrm{p}<0,0001$ \\
\hline AGE & $1,17[1,1-1,4]$ & $1,07[0,9-1,2]$ & $\mathrm{p}=0,0004$ \\
\hline $\mathrm{BMI}-\mathrm{kg} / \mathrm{m}^{2}$ & $28,5[25,1-34,1]$ & $25,7[22,6-29,4]$ & $\mathrm{p}<0,0001$ \\
\hline Charlson-féle komorbiditási index & $1,93 \pm 0,11$ & $1,75 \pm 0,11$ & NS \\
\hline $\mathrm{CRP}-\mathrm{mg} / \mathrm{l}$ & $135,1[67,3-232,7]$ & $152,7[83,2-220,8]$ & NS \\
\hline Fehérvérsejtszám - G/1 & $12,5[9,6-17,2]$ & $13,8[10,5-18,6]$ & NS \\
\hline $\mathrm{PCT}-\mathrm{ng} / \mathrm{ml}$ & $0,86[0,26-6,64]$ & $2,04[0,40-7,42]$ & NS \\
\hline Szepszisprevalencia - \% & $56,1 \%$ & $61,9 \%$ & NS \\
\hline Halálozás (bent fekvés) - \% & $10,7 \%$ & $9,9 \%$ & NS \\
\hline Halálozás (3 hó) - \% & $19,0 \%$ & $20,8 \%$ & NS \\
\hline
\end{tabular}

Az értékek a medián [25-75\% percentilis]-t jelölik, kivéve a Charlson-féle komorbiditási indexet, ami átlag \pm SE-t (standard hiba) jelent.

A szepszist a SIRS- (systemic inflammatory response syndrome) kritériumok alapján definiáltuk: 1 ) testhőmérséklet $>38^{\circ} \mathrm{C}$ vagy $<36{ }^{\circ} \mathrm{C}, 2$ ) szívfrekvencia $>90$ /perc, 3) légzésszám $>20$ /perc vagy artériás $\mathrm{PCO}_{2}<32 \mathrm{Hgmm}$, 4) fehérvérsejtszám $>12000 / \mathrm{mm}^{3}$ vagy $<4000 / \mathrm{mm}^{3}$. A két csoport közti szignifikáns különbségek meghatározására Mann-Whitney-féle vagy chi-négyzet-tesztet végeztünk.

AGE = késői glikációs végtermékek; $\mathrm{BMI}=$ testtömegindex; $\mathrm{CRP}=\mathrm{C}$-reaktív protein; $\mathrm{NS}=$ nem szignifikáns; $\mathrm{OAD}=$ orális antidiabetikum; $\mathrm{PCT}=$ prokalcitonin 


\section{Laborvizsgálat}

A CRP-t (hsCRP) turbidimetriás módszerrel (Beckman Coulter, Inc., Brea, CA, Amerikai Egyesült Államok [USA]), a többi klinikai labor paramétert Beckman Coulter vagy Cell-Dyn 3500 'hematology analyzer'-rel határoztuk meg. A vércukrot hexokinázassay, a fruktózaminszintet Roche Fructosamine kolorimetriás kit (Roche Diagnostic Systems, Inc., Rahway, NJ, USA; 'nitrotetrazolium blue chloride', Beckman Analyzer AU680, referenciaszint: $205-280 \mu \mathrm{mol} / \mathrm{l})$, a $\mathrm{HbA}_{\mathrm{lc}}$-t ioncsere nagynyomású folyadékkromatográfia alkalmazásával (HPLC, referenciaszint: 4,0-6,0\%) határoztuk meg. A kései glikációs végtermékeket (AGE) a bőrből, noninvazív autofluoreszcens technika (AGE Reader mu, DiagnOptics Technologies BV, Groningen, Hollandia) segítségével adtuk meg [4l].

\section{Statisztika}

A statisztikai számításokat GraphPad Prism 5 (Graphpad Software, Inc., La Jolla, CA, USA, www.graphpad.com) szoftver segítségével végeztük. A folyamatos változókat medián és $25-75 \%$ percentilisben, a kategorikusokat $\mathrm{N}$; \%-ban adtuk meg. A két független csoport közti különbséget Mann-Whitney- vagy Fisher-egzakt teszttel kalkuláltuk. Minden statisztikai analízis kétoldali (two-tailed), a szignifikancia határa $\mathrm{p}=0,05$ volt.

\section{Eredmények}

\section{Általános klinikai jellemzők}

A vizsgálatba összesen bevont 205 T2DM- és 202 Kbeteg adatait az 1. táblázat foglalja össze. A két csoport életkor- és nembeli megoszlása, valamint Charlson-féle komorbiditási indexe nem különbözött egymástól. Mind a felvételi vércukor-, mind a rövid (fruktózamin), közepes $\left(\mathrm{HbA}_{\mathrm{lc}}\right)$ és hosszú távú glikációs paraméterek (AGE), és a testtömegindex (BMI) nagyobb volt a cukorbetegeknél, mint a kontrollcsoportban ( $\mathrm{p}=0,0004$ az AGE, $\mathrm{p}<0,0001$ a többi paraméter esetén). A T2DM-csoport cukorbetegség-tartama 14 év, medián $\mathrm{HbA}_{\mathrm{lc}}$-je 7,5\% volt. Az antidiabetikumterápia a kórházi felvételkor az alábbi módon alakult: csak diéta $(16,6 \%)$, diéta + orális antidiabetikum (OAD) (41,9\%), diéta + OAD és inzulin $(16,1 \%)$, valamint diéta + csak inzulin $(25,4 \%)$.

$\mathrm{Az}$ infekciót jellemző laboratóriumi eredmények a referenciatartomány felett voltak (C-reaktív protein $>100$ $\mathrm{mg} / \mathrm{l}$, fehérvérsejtszám $>12 \mathrm{G} / 1$, prokalcitonin >0,5 $\mathrm{ng} / \mathrm{ml}$; mindkét csoportban). A két betegpopuláció között különbséget ezen változók tekintetében nem találtunk. A kórházba kerüléskor a SIRS-kritériumok alapján számított szepszisprevalencia statisztikailag nem különbözött: T2DM esetén 56\%, K esetén $61 \%$ felett volt. A szepszis megléte mindkét csoporton belül korrelált a CRP-vel $(\mathrm{p}<0,0001, \mathrm{r}=0,34$ a T2DM és $\mathrm{p}=0,003$,
2. táblázat $\mid$ Az egyes infekciók csoportosítása lokalizáció szerint

\begin{tabular}{llll}
\hline & $\begin{array}{l}\text { 2-es típusú diabeteses } \\
(\mathrm{n}=205)\end{array}$ & $\begin{array}{l}\text { Nem diabeteses } \\
(\mathrm{n}=202)\end{array}$ & Szignifikancia \\
\hline Légúti & $46 ; 22,4 \%$ & $75 ; 37,1 \%$ & $\mathrm{p}=0,0024$ \\
Húgyúti & $64 ; 31,2 \%$ & $64 ; 31,7 \%$ & $\mathrm{NS}$ \\
SSTI & $76 ; 37,1 \%$ & $46 ; 22,8 \%$ & $\mathrm{p}=0,0017$ \\
$\begin{array}{l}\text { SSTI - alsó } \\
\text { végtagon }\end{array}$ & $66 / 76 ; 86,8 \%$ & $36 / 46 ; 78,3 \%$ & $\mathrm{p}=0,0009$ \\
Egyéb & $19 ; 9,3 \%$ & $17 ; 8,4 \%$ & $\mathrm{NS}$ \\
\hline
\end{tabular}

SSTI (skin- and soft tissue infection): bőr- és lágyrész-fertőzés. Az értékek a betegek számát és \%-ban megadott, összes infekcióhoz viszonyított relatív gyakoriságát jelölik infekciólokalizáció szerint csoportosítva. A két csoport közti különbségek meghatározása Fisher-egzakt teszttel történt.

NS = nem szignifikáns

$\mathrm{r}=0,21$ a $\mathrm{K}$ esetén), továbbá a T2DM-csoport esetén összefüggést mutatott a felvételi vércukorral $(\mathrm{p}=0,004$, $\mathrm{r}=0,21)$.

\section{Az infekciók jellemzése lokalizáció szerint}

Az infekciókat helyük szerint négy csoportra osztottuk: légúti, húgyúti, bőr- és lágyrész- (SSTI: skin- and soft tissue infection) fertőzések és egyéb. A légútiak között a leginkább pneumonia és COPD akut exacerbatiója, a húgyútiaknál föként akut pyelonephritis, az SSTI-k között erysipelas, cellulitis, diabeteses láb, egyéb esetben pedig fóként akut cholecystitis, diverticulitis, cholangitis fordult elő. A leggyakoribb típus a cukorbetegekben a bőr- és lágyrész-fertőzés $(37,1 \%)$, nem cukorbetegekben a légúti infekció volt $(37,1 \%)$. Ezeket mindkét csoportban a húgyúti infekciók követték (31,2\% vs. 31,7\%) (2. táblázat).

A két betegcsoport egyes infekciótípusait összehasonlítva T2DM-betegeknél a bőr- és lágyrész-lokalizációjúak nagyobb, míg a légúti infekciók kisebb arányban fordultak elő, mint a $\mathrm{K}$ csoportban $(37,1 \%$ vs. $22,8 \%, \mathrm{p}=$ 0,0017 az SSTI-re, $22,4 \%$ vs. $37,1 \%, p=0,0024$ a légútira vonatkozóan) (2. táblázat). Az SSTI-k közül cukorbetegek esetén 66/76, nem diabeteseseknél 36/46 érintette az alsó végtagot. A húgyúti és egyéb fertőzések előfordulását illetően nem találtunk különbséget a két csoport között.

\section{Mikrobiológiai eredmények}

A betegek tüneteinek megfelelően mikrobiológiai tenyésztés céljából mintákat vettünk (hemokultúra, vizelet- és sebváladék-tenyésztés). Alsó légúti tenyésztés (bronchoalveolaris lavage - BAL) nem történt. Pozitív tenyésztési eredményt a cukorbetegek 55,1\%-ánál és a nem cukorbetegek 48,5\%-ánál találtunk, szeptikus betegek esetén a hemokultúra-pozitivitás T2DM esetén 
A kórokozók Gram-festés szerinti csoportosítása a pozitív tenyésztési eredmények alapján a bőr- és lágyrész-infekciókban

\begin{tabular}{lllll}
\hline & & $\begin{array}{l}\text { 2-es típusú } \\
\text { diabeteses }\end{array}$ & $\begin{array}{l}\text { Nem } \\
\text { diabeteses }\end{array}$ & Szignifikancia \\
\hline $\begin{array}{l}\text { Bôr- és } \\
\text { lágyrész- } \\
\text { fertôzés }\end{array}$ & $\begin{array}{l}\text { Pozitív } \\
\text { tenyésztések }\end{array}$ & $47 / 76$ & $20 / 46$ & NS \\
& Gram+ & 13 & 10 & NS \\
& Gram- & 11 & 5 & NS \\
& Gram+ és Gram- & 23 & 5 & $\mathrm{p}=0,0149$ \\
\hline
\end{tabular}

A táblázat a pozitív tenyésztések előfordulását mutatja bőr- és lágyrészinfekciókban (sebváladék-tenyésztés és/vagy hemokultúra) Gram-festés alapján csoportosítva. Az egyes T2DM- és K alcsoportok közti különbségek meghatározása Fisher-egzakt teszttel történt.

$\mathrm{NS}=$ nem szignifikáns; $\mathrm{T} 2 \mathrm{DM}=2$-es típusú cukorbetegség

4. táblázat $\mid$ Pozitív vizelet- és/vagy hemokultúra-tenyésztési eredmények húgyúti infekciók esetén

\begin{tabular}{llll}
\hline & $\begin{array}{l}\text { 2-es típusú } \\
\text { diabeteses } \\
(\mathrm{n}=64)\end{array}$ & $\begin{array}{l}\text { Nem } \\
\text { diabeteses } \\
(\mathrm{n}=64)\end{array}$ & Szignifikancia \\
\hline Pozitív tenyésztés (összes) & $47 ; 73,4 \%$ & $53 ; 82,8 \%$ & NS \\
Csak E. coli & $20 ; 42,6 \%$ & $32 ; 60,4 \%$ & NS \\
Csak Klebsiella & $4 ; 8,5 \%$ & $7 ; 13,2 \%$ & NS \\
Egyéb monopatogénes & $7 ; 14,9 \%$ & $6 ; 11,3 \%$ & NS \\
Polimikrobás & $16 ; 34,0 \%$ & $8 ; 15,1 \%$ & $\mathrm{p}=0,0335$ \\
\hline
\end{tabular}

A táblázat a pozitív vizelet- és/vagy hemokultúra-tenyésztések során talált uropatogén baktériumokat csoportosítja. E. coli= Escherichia coli; Csak Klebsiella = Klebsiella pneumoniae / oxytaca. A "polimikrobás” csoportba azon tenyésztési eredmények kerültek bele, melyekből több, mint egy uropatogén baktérium tenyészett ki. Az összes pozitív tenyésztés esetszámát követő \%-os érték az összes húgyúti infekcióhoz viszonyított relatív gyakoriságot jelöli. Az alcsoportok esetén az esetszámot követő \%-os érték az összes pozitív tenyésztéshez viszonyított relatív gyakoriságot jelöli. A két csoport közti különbségek meghatározása Fisher-egzakt teszttel történt.

NS = nem szignifikáns

36,9\%, a K csoportban 47\% volt. A kórokozókat részben Gram-festés szerint csoportosítottuk: csak Gram-pozitív (Gram+), csak Gram-negatív (Gram-), valamint Gram+ és Gram- kórokozókat egyaránt tartalmazó alcsoportok. A Gram+ és Gram- kórokozókat egyaránt tartalmazó tenyésztések száma a T2DM-csoportban magasabb volt, mint a nem diabeteseseknél (a pozitív tenyésztések 23,1\%-a vs. 9,2\%-a, p = 0,0089). Ezt a különbséget leginkább az SSTI-k okozták: a T2DM-csoport ezen infekcióiban magasabb volt a Gram+ és Gram- kórokozókat egyaránt tartalmazó alcsoport relatív gyakorisága, mint a nem cukorbeteg csoportban $(23 / 76$ vs. $5 / 46, \mathrm{p}=$ 0,0149) (3. táblázat).

A húgyúti infekciók elemzése során az uropatogéneket a pozitív vizelet- és/vagy hemokultúra-tenyésztések alapján az alábbi csoportokra osztottuk: csak E. coli, csak
Klebsiella (Klebsiella pneumoniae és oxytoca), egyéb monopatogénes (Enterococcus faecalis és faecium / Proteus mirabilis / Providencia stuartii / Morganella morganii / Pseudomonas aeruginosa / Staphylococcus aureus) és polimikrobás (4. táblázat). A polimikrobás csoportba azon tenyésztési eredmények kerültek bele, melyekből több, mint egy uropatogén kórokozó tenyészett ki. Az összes pozitív tenyésztési gyakoriságot illetően nem találtunk különbséget (73,4 vs. 82,8\%). A T2DM-csoportban a polimikrobás infekciók nagyobb arányban fordultak elő a $\mathrm{K}$ csoporthoz képest $(34,0 \%$ vs. $15,1 \%$, p = $0,0335)$. A kizárólag E. coli okozta fertőzések bizonyultak a leggyakoribbnak mindkét csoportban; a cukorbetegeknek mintegy a 43\%-ában, a nem cukorbetegeknek pedig több mint a $60 \%$-ában. Statisztikailag ez a különbség nem bizonyult szignifikánsnak. A Klebsiella és egyéb kórokozók tekintetében nem volt eltérés a két betegpopuláció között. Az alacsony pozitív mikrobiológiai (hemokultúra) mintaszám és a BAL hiányában a légúti, az alacsony esetszám miatt az egyéb fertőzések nem kerültek feltüntetésre.

Az egyes infekciókban a leggyakrabban választott antibiotikumokat - mindkét csoportot összesítve - mutatja be az 5. táblázat. Légúti fertőzéseknél ceftriaxon ( \pm klaritromicin) vagy fluorokinolon, húgyúti esetén cefalosporin (a leginkább ceftriaxon), míg SSTI esetén penicillinszármazékok (a leginkább amoxicillin/klavulánsav) voltak az elsőként választott empirikus szerek között. Obszervációs vizsgálatunkban azt tapasztaltuk, hogy az empirikus antibiotikum választását nem befolyásolta a cukorbetegség megléte vagy hiánya.

\section{Mortalitás}

Sem a bent fekvés alatti, sem a felvételt követő 3 hónapos halálozásban nem találtunk különbséget a két csoport között (T2DM: 10,7\% és 19\% vs. K: 9,9\% és 20,8\%; nem szignifikáns) (1. és 6. táblázat). T2DM esetén a bőr- és lágyrész-fertőzések $(23,7 \%)$, a nem cukorbetegeknél pedig a légúti infekciók $(29,3 \%)$ okozták a legtöbb halált. A T2DM-betegek bőr- és lágyrész-infekcióinak relatív mortalitása magasabbnak, a légúti fertőzéseké pedig alacsonyabbnak tűnik, mint a nem cukorbetegek ezen in-

\section{5. táblázat $\mid$ Az elsóként választott, empirikus antibiotikummal végzett terá- pia az infekció helye szerint, mindkét csoportot együttesen ele- mezve}

\begin{tabular}{|c|c|c|}
\hline Infekciótípus & $\begin{array}{l}\text { Az 1. leggyakoribb } \\
\text { empirikus antibiotikum }\end{array}$ & $\begin{array}{l}\text { A 2. leggyakoribb } \\
\text { empirikus antibiotikum }\end{array}$ \\
\hline Légúti & $\begin{array}{l}\text { Cefalosporin } \pm \text { makrolid } \\
\text { / fluorokinolon }\end{array}$ & Penicillinszármazék \\
\hline Húgyúti & Cefalosporin & $\begin{array}{l}\text { Karbapenem / } \\
\text { fluorokinolon }\end{array}$ \\
\hline $\begin{array}{l}\text { Bőr- és } \\
\text { lágyrész-beli }\end{array}$ & Penicillinszármazék & $\begin{array}{l}\text { Cefalosporin / } \\
\text { karbapenem / } \\
\text { ciprofloxacin + } \\
\text { klindamicin }\end{array}$ \\
\hline
\end{tabular}


6. táblázat | 3 hónapos mortalitások az egyes infekciókban

\begin{tabular}{llll}
\hline & $\begin{array}{l}\text { 2-es típusú diabeteses } \\
(\mathrm{n}=205)\end{array}$ & $\begin{array}{l}\text { Nem diabeteses } \\
(\mathrm{n}=202)\end{array}$ & Szignifikancia \\
\hline Összes & $19,0 \%$ & $20,8 \%$ & $\mathrm{NS}$ \\
Légúti & $10 / 46 ; 21,7 \%$ & $22 / 75 ; 29,3 \%$ & $\mathrm{NS}$ \\
Húgyúti & $9 / 64 ; 14,1 \%$ & $10 / 64 ; 15,6 \%$ & $\mathrm{NS}$ \\
$\begin{array}{l}\text { Bór- és } \\
\text { lágyrész-beli }\end{array}$ & $18 / 76 ; 23,7 \%$ & $8 / 46 ; 17,4 \%$ & $\mathrm{NS}$ \\
Egyéb & $2 / 19 ; 10,5 \%$ & $2 / 17 ; 11,8 \%$ & $\mathrm{NS}$ \\
\hline
\end{tabular}

A táblázat a 3 hónapos mortalitási adatokat mutatja be. Az összes halálozásnál a mortalitást az összes infekcióra vonatkozólag adtuk meg. Az egyes infekciótípusoknál a mortalitást az adott infekciótípusra vonatkozólag jelöltük (adott infekcióban meghalt/összes adott infekció száma; \%-ban kifejezett gyakoriság). A két csoport közti különbségek meghatározása Fisher-egzakt teszttel történt.

NS = nem szignifikáns

fekciós halálozásai, szignifikáns különbséget azonban sem e tekintetben, sem a többi infekciós lokalizáció esetén nem találtunk (6. táblázat).

A kórházban meghalt betegeket a túlélőkhöz viszonyítva mindkét vizsgálati csoport esetén magasabb Charlson-féle komorbiditási indexet (átlagok 2,86 vs. $1,82, \mathrm{p}=0,006$ a T2DM- és 2,79 vs. $1,61, \mathrm{p}=0,005$ a K csoport esetén), a T2DM-csoporton belül emelkedettebb fehérvérsejtszámot ( 16,8 vs. $12,4 \mathrm{G} / 1, \mathrm{p}=0,02)$, a nem cukorbetegeknél pedig magasabb életkort ( 80,0 vs. 71,0 év, p = 0,002) regisztráltunk. Nem találtunk különbséget egyik csoporton belül sem a felvételi vércukorszint, a CRP és a vesefunkció vonatkozásában.

\section{Megbeszélés}

Eredményeink a kórházi felvételt igénylő, területen szerzett bakteriális infekciók részletes elemzéséül szolgálnak 2-es típusú cukorbetegségben, és lehetővé teszik a nem cukorbeteg populáció hasonló infekcióival, illetve a nemzetközi vizsgálatokkal való összehasonlítást. A T2DMbetegek között nagyobb arányban találtunk bőr- és lágyrész-fertőzést és kisebb hányadban légúti infekciót, mint nem cukorbetegek esetében. Mind a T2DM-, mind a nem cukorbeteg csoportban a húgyúti fertőzések jelentették a második leggyakoribb infekciót. A fertőzést jellemző laborparaméterekben (CRP, PCT, fehérvérsejtszám) és a szepszis gyakoriságában nem találtunk különbséget a két csoport között. A kórokozóspektrumot illetően a cukorbetegek bőr- és lágyrész-infekcióiban nagyobb arányban mutattunk ki egyidejúleg Gram+ és Gram- baktériumokat, míg a húgyúti fertőzésekben polimikrobás eredetúeket, mint a nem cukorbeteg csoportban. Nem találtunk különbséget a két csoport között a bent fekvés alatti és a 3 hónapos halálozás tekintetében, sem összességében, sem az egyes infekciókra vonatkozóan. Mindkét csoportban nagyobb volt a társ- betegségek száma a kórházban elhunytak között. A bent fekvés alatti halálozás a T2DM-csoportban a nagyobb felvételi fehérvérsejtszámmal, a nem cukorbeteg csoportban a magasabb életkorral állt összefüggésben.

A konszekutív módon bevont betegek száma kellően nagy ahhoz, hogy jellemezhessük a belgyógyászati osztályos felvételt igénylő bakteriális infekciókat 2-es típusú cukorbetegségben a nem cukorbetegek ezen infekcióival összehasonlítva. Prospektív vizsgálatunk erőssége, hogy mindkét csoport több, mint 200 beteg adatait tartalmazza érdemi nemi és életkorbeli különbség nélkül a két csoport között. Kutatásunk nem ad választ a bakteriális infekciók gyakoriságára 2-es típusú cukorbetegségben, illetve hogy időegység alatt több vagy kevesebb kórházi felvétel történik-e infekció miatt a nem cukorbeteg népességhez képest.

Eredményeinkhez hasonlóan a bőr- és lágyrész-fertőzések gyakoribb előfordulását találta T2DM esetén egy nemrégiben megjelent tanulmány, mely bakteriális fertőzés miatt hospitalizált mintegy 8000 beteg adatait dolgozta fel [17]. Akirov és mtsai azonban velünk ellentétben légúti fertőzésbeli különbséget a két csoport között nem tapasztalt. A mi T2DM-csoportunknál kiugróan magas volt a bőr- és lágyrész-fertőzések aránya a fenti közlemény adataival összehasonlítva (37,1\% vs. 16\%) [17]. Vélhetően ez is szerepet játszott a relatíve alacsonyabb légútifertőzés-előfordulással kapcsolatos megfigyeléseinkben, ennek oka azonban nem tisztázható teljesen. A háttérben állhat még az a körülmény is, hogy a légúti fertőzésben szenvedő betegek súlyosságuk és diagnózisuk alapján más profilú osztályra, illetve intézménybe kerülhettek. Annak a lehetősége is felmerül, hogy cukorbetegek nagyobb valószínúséggel élnek a légúti fertőzések elleni védőoltásokkal (például Pneumococcus, influenza), az erre vonatkozó vizsgálati adataink azonban nem voltak kellően megbízhatók. A cukorbetegek fertőzései közül az SSTI-vel talált legerősebb rizikóbeli összefüggést egy másik, az alapellátásban ellátott betegek eredményeit feldolgozó nemzetközi követéses vizsgálat is [12]. Hazai, nagy számú, a cukorbetegek bakteriális fertőzéseit felmérő tanulmány tudomásunk szerint nem áll rendelkezésre. Ennek hiányában és a mi eredményünket figyelembe véve nehéz választ adni arra, hogy a hazai cukorbetegek - más országokhoz viszonyítva - nagyobb veszélyben vannak-e a bőr- és lágyrész-fertőzést illetően. Tény, hogy Magyarországon közel háromszor annyi a lábamputációk száma, mint az Európai Unió többi országában, és ennek jelentős része a diabeteshez köthető [42]. Ezt a szomorú adatot fóleg a kevesebb érsebészeti beavatkozásnak tulajdonítják. Ezen túlmenően fontos különbség lehet az önálló „lábambulanciák", valamint a független podiáteri szakképesítés külföldön való megléte is. Hazánkban a podiáterhallgatók képzése már megkezdődött, jelenleg a második évfolyam posztgraduális oktatása zajlik. Ha ezek az új szakemberek a közeljövőben egyre nagyobb számban munkába állnak, ez nem csupán a diabetesesek fertőzéseit, hanem 
- a sokszor indokolatlan - csonkolások magas számát is jelentősen redukálni fogja. Nem lehet elégszer hangsúlyoznia a primer prevenció fontosságát a diabeteseslábszövődmények megelőzésében. Fontos továbbá, hogy mindenki számára elérhető legyen a megfelelő érsebészeti kivizsgálás és ellátás. Ugyancsak jelentős előrelépést jelent, hogy 2018-ban - az érintett szakmák bevonásával - külön szakmai irányelv jelent meg a diabeteses láb vonatkozásában [43].

Vizsgálatunkban a bőr- és lágyrész-infekciókban a T2DM-csoportban a leggyakrabban a Gram+ és Gramkórokozók együttes jelenléte volt kimutatható. A nem diabeteses csoportban a Gram+ baktériumok fordultak elő a legtöbbször. Egy, a bőr- és lágyrész-infekciók kórokozóit jellemző korábbi összehasonlító tanulmány a Gram-negatív kórokozókat inkább a diabeteses, a Grampozitívokat pedig a nem diabeteses betegekkel hozta öszszefüggésbe [44]. Ezen túlmenően a nem cukorbetegek infekciói során nagyobb valószínűséggel talált monomikrobiális eredetet, mint cukorbetegekben, ami párhuzamba hozható a mi eredményeinkkel. Meg kell jegyezni, hogy nem minden vizsgálat ír le ilyen éles különbséget Gram+ és Gram- patogénekre vonatkozóan, és a bevezetésben említett bangladesi tanulmány is mindkét csoport fertőzéseinek inkább polimikrobás természetéről számol be [36]. Az SSTI-k polimikrobás tenyésztési eredményeiről általában megemlítendő, hogy terápiás szempontból nem mindegy, melyik baktériumot tekintjük valóban kórokozónak, melyiket pedig kontaminációnak. Ezekben az esetekben a baktériumok típusa, a korábbi tenyésztési eredmények, valamint a párhuzamosan más tenyésztések (hemokultúra) pozitivitása segíthet; kérdéses esetben infektológiai szakorvosi vélemény válhat szükségessé.

A cukorbetegségben fellépő húgyúti infekciók relatíve alacsonyabb E. coli-előfordulásáról már szóltunk [29, 30, 31, 45]. Vizsgálatunkban a T2DM-csoportban számszerúen kevesebb, E. coli okozta húgyúti fertőzés volt (monopatogén) a nem diabeteses csoporthoz képest (20/47 vs. 32/53); a különbség a két csoport között nem volt szignifikáns. Véleményünk szerint ez leginkább az esetszámmal állhat összefüggésben. Nem elhanyagolható szempont lehet, hogy betegeink területen szerzett, nem pedig nosocomialis infekciókban szenvedtek, míg az ezzel kapcsolatos nemzetközi eredmények általában nem tesznek különbséget e tekintetben. A polimikrobás eredetű húgyúti fertőzés cukorbetegeinknél talált magasabb gyakorisága megfelel a korábbi nemzetközi irodalmi adatoknak [46].

Jelen megfigyelésünk nem mutatott különbséget a (kórházon belüli és a 3 hónapos) mortalitási adatokban a két csoport között. Két nemrég publikált nagy betegszámú (901 136 és 29 683) tanulmány hozzánk hasonlóan nem talált eltérést a bent fekvés során, illetve az azt követő 28 napos mortalitás terén a két betegcsoport között [47, 48]. Korábban, pneumonia miatt kórházba került összesen 29900 beteg követéses vizsgálatában a cukor- betegeknél rosszabb 30 napos és 3 hónapos mortalitást találtak (Kornum és mtsai) [15]. Akirov és mtsai a már előzőleg említett tanulmányban szintén hasonló következtetéseket vontak le [17]. Ez a két vizsgálat a magasabb halálozást a felvételkori magas vércukorral is összefüggésbe hozta (Kornum: $14 \mathrm{mmol} / \mathrm{l} \leq$; Akirov: 180 $\mathrm{mg} / \mathrm{dl} \leq$ ), a betegek korábbi krónikus glikációs paraméterei és a diabetestartam azonban nem vagy csak részben volt ismert; az előbbinél pedig a cukorbetegek medián életkora magasabb volt, mint a kontrollcsoporté [15]. Nemzetközi adatok alapján a különböző lokalizációjú infekciók közül az SSTI kórházi halálozása általában kisebb, mint a légúti fertőzéseké $[15,17,49]$. A mi vizsgálatunkban a T2DM-csoport legyakoribb fertőzése az SSTI volt, míg a nem diabeteses csoportban a légúti. A felvételi vércukorszint a T2DM-csoportban - az infekció ellenére - a legtöbb esetben elfogadható volt (medián 10,8 mmol/l). Ezek részben magyarázhatják, hogy mi miért nem észleltünk halálozásbeli különbséget a két csoport között. Kiemelendő, hogy a nem cukorbetegeink kórházon belüli mortalitása gyakorlatilag megegyezik Akirovék eredményeivel (9,9\% vs. 10\%). Ez amellett szól, hogy a mi vizsgálatunkban a két betegcsoport azonos, kórházon belüli halálozását a cukorbetegek relatíve jobb túlélése okozhatta. Ennek egyik oka az infekció alatt folytatott terápia lehet. Az említett vizsgálatokban [15, 17] nem esik szó az antibiotikumterápiáról, ezek hiányában nehéz erre vonatkozó következtetést levonni. A vizsgálatba bevont cukorbetegeinknél naponta többször mértünk praeprandialis vércukorszintet, ellátásukat ennek megfelelően módosítottuk, törekedve a közel normoglykaemia elérésére (praeprandialis vércukorszintcélérték: 5-8 mmol/l). Egy másik lehetséges tényező a cukorbetegeink relatíve elfogadható $\mathrm{HbA}_{1 \mathrm{c}}$-statusa, még úgy is, hogy a $\mathrm{HbA}_{\mathrm{lc}}$-t ismerten súlyozottan befolyásolja a mérést megelőző néhány hét átlagos vércukorszintje, és így a gyulladás okozta stressz kapcsán a $\mathrm{HbA}_{1 \mathrm{c}}$-értékeink valószínúleg némiképp még magasabbak is, mint egyébként lennének [50]. Véleményünk szerint ezek a faktorok mind szerepet játszhattak a T2DM-csoport - a fenti vizsgálatok eredményeihez képest - kedvezőbb mortalitási mutatóiban.

\section{Következtetések}

Területen szerzett, bakteriális infekció miatt belgyógyászati osztályra felvételre került 2-es típusú cukorbetegeinknél a nemzetközi adatokhoz képest nagyobb arányban találtunk bőr- és lágyrész-fertőzést. A mortalitás is ebben az infekciótípusban volt a legmagasabb a cukorbeteg csoportban. Kórokozóként a leggyakrabban Grampozitív és Gram-negatív baktériumok együttes jelenlétét tudtuk kimutatni, ami különbség a nem diabeteses csoport hasonló típusú infekciójához képest. Húgyúti fertőzés során a cukorbetegeknél nagyobb valószínúséggel találkozhatunk polimikrobás infekcióval. Az összes infekció vonatkozásában a rövid távú mortalitásban nem 
találtunk különbséget a 2-es típusú cukorbeteg és a nem cukorbeteg csoport között. Ez utóbbi eredmény az újabb nemzetközi adatokat támasztja alá. A kedvezően alakuló halálozási adatokban a megfelelő anyagcsere-vezetésnek lehet szerepe, míg a bőr- és lágyrész-fertőzésnek a nemzetközi adatokhoz képest jelentősen gyakoribb előfordulása a primer prevenció fontosságára és hazai elégtelenségére hívja fel a figyelmet 2-es típusú cukorbetegségben.

Anyagi támogatás: Dr. Korányi András Alapítvány, EFSD New Horizons, Az orvos-, egészségtudományi- és gyógyszerészképzés tudományos múhelyeinek fejlesztése (EFOP-3.6.3-VEKOP-16-2017-00009), MDT Novo Nordisk.

Szerzői munkamegosztás: A vizsgálatot H. N., S. E., Cs. D. és P. Z. tervezte. A vizsgálatba a betegeket B. L. J. és S. E. válogatta be B. T., N. Zs., M. A., K. I., P. P. és H. N. segítségével. A betegek klinikai és laboratóriumi adatait B. L. J. és S. E. gyưjtötte össze. Az adatok kezelését és a statisztikai számításokat B. L. J. végezte. A kéziratot B. L. J. írta H. N., S. E., Cs. D. és P. Z. kritikus revíziója segítségével. A cikk végleges változatát valamennyi szerző elolvasta és jóváhagyta.

Érdekeltségek: A szerzőknek nincsenek érdekeltségeik.

\section{Irodalom}

[1] Knapp S. Diabetes and infection: is there a link? - A mini-review. Gerontology 2013; 59: 99-104.

[2] Koh GC, Peacock SJ, van der Poll T, et al. The impact of diabetes on the pathogenesis of sepsis. Eur J Clin Microbiol Infect Dis. 2012; 31: 379-388.

[3] Restrepo BI. Convergence of the tuberculosis and diabetes epidemics: renewal of old acquaintances. Clin Infect Dis. 2007; 45 $436-438$.

[4] Karaman E, Yilmaz M, Ibrahimov M, et al. Malignant otitis externa. J Craniofac Surg. 2012; 23: 1748-1751

[5] Ludwig E. Urinary tract infections in diabetes mellitus. [Húgyúti infekciók diabetes mellitusban.] Orv Hetil. 2008; 149: 597-600. [Hungarian]

[6] Joshi, N, Mahajan M. Infection and diabetes. In: Pickup JC, Williams G. (eds.) Textbook of diabetes. Blackwell Science, Oxford, UK, 2003; pp. 40.1-40.16.

[7] Tsai FC, Huang YT, Chang LY, et al. Pyogenic liver abscess as endemic disease, Taiwan. Emerg Infect Dis. 2008; 14: 15921600.

[8] Cheng AC, Currie BJ. Melioidosis: epidemiology, pathophysiology, and management. Clin Microbiol Rev. 2005; 18: 383-416.

[9] Shah BR, Hux JE. Quantifying the risk of infectious diseases for people with diabetes. Diabetes Care 2003; 26: 510-513.

[10] Muller LM, Gorter KJ, Hak E, et al. Increased risk of common infections in patients with type 1 and type 2 diabetes mellitus. Clin Infect Dis. 2005; 41: 281-288.

[11] Carey IM, Critchley JA, DeWilde S, et al. Risk of infection in type 1 and type 2 diabetes compared with the general population: a matched cohort study. Diabetes Care 2018; 41: 513-521.

[12] Abu-Ashour W, Twells LK, Valcour JE, et al. Diabetes and the occurrence of infection in primary care: a matched cohort study. BMC Infect Dis. 2018; 18: 67.
[13] Jackson LA. Evaluating diabetes mellitus as a risk factor for com munity-acquired infections. Clin Infect Dis. 2005; 41: 289-290.

[14] Davis TM, Weerarathne T, Foong Y, et al. Community-acquired infections in type 2 diabetic patients and their nondiabetic partners: the Fremantle Diabetes Study. J Diabetes Complications $2005 ; 19: 259-263$.

[15] Kornum JB, Thomsen RW, Riis A, et al. Type 2 diabetes and pneumonia outcomes: a population-based cohort study. Diabetes Care 2007; 30: 2251-2257.

[16] Rao Kondapally Seshasai S, Kaptoge S, Thompson A, et al. Diabetes mellitus, fasting glucose, and risk of cause-specific death. N Engl J Med. 2011; 364: 829-841.

[17] Akirov A, Diker-Cohen T, Masri-Iraqi H, et al. Outcomes of hyperglycemia in patients with and without diabetes hospitalized for infectious diseases. Diabetes Metab Res Rev. 2018; 34: e3027.

[18] Benfield T, Jensen JS, Nordestgaard BG. Influence of diabetes and hyperglycaemia on infectious disease hospitalisation and outcome. Diabetologia 2007; 50: 549-554.

[19] Stegenga ME, Vincent JL, Vail GM, et al. Diabetes does not alter mortality or hemostatic and inflammatory responses in patients with severe sepsis. Crit Care Med. 2010; 38: 539-545.

[20] Tsai CL, Lee CC, Ma HM, et al. Impact of diabetes on mortality among patients with community-acquired bacteremia. J Infect. 2007; 55: 27-33.

[21] Esper AM, Moss M, Martin GS. The effect of diabetes mellitus on organ dysfunction with sepsis: an epidemiological study. Crit Care 2009; 13: Rl8.

[22] Mor A, Dekkers OM, Nielsen JS, et al. Impact of glycemic control on risk of infections in patients with type 2 diabetes: a population-based cohort study. Am J Epidemiol. 2017; 186: 227236.

[23] Pearson-Stuttard J, Blundell S, Harris T, et al. Diabetes and infection: assessing the association with glycaemic control in population-based studies. Lancet Diabetes Endocrinol. 2016; 4: $148-158$.

[24] Delamaire M, Maugendre D, Moreno M, et al. Impaired leucocyte functions in diabetic patients. Diabet Med. 1997; 14: 2934.

[25] Repine JE, Clawson CC, Goetz FC. Bactericidal function of neutrophils from patients with acute bacterial infections and from diabetics. J Infect Dis. 1980; 142: 869-875.

[26] MacCuish AC, Urbaniak SJ, Campbell CJ, et al. Phytohemagglutinin transformation and circulating lymphocyte subpopulations in insulin-dependent diabetic patients. Diabetes 1974; 23: 708-712.

[27] Lapolla A, Tonani R, Fedele D, et al. Non-enzymatic glycation of IgG: an in vivo study. Horm Metab Res. 2002; 34: 260-264.

[28] Barkai LJ, Sipter E, Csuka D, et al. Decreased ficolin-3-mediated complement lectin pathway activation and alternative pathway amplification during bacterial infections in patients with type 2 diabetes mellitus. Front Immunol. 2019; 10: 509.

[29] Brown JS, Wessells H, Chancellor MB, et al. Urologic complications of diabetes. Diabetes Care 2005; 28: 177-185.

[30] Ronald A, Ludwig E. Urinary tract infections in adults with diabetes. Int J Antimicrob Agents 2001; 17: 287-292.

[31] Timár L. Diabetes and infections. [Diabetes és infekciók.] Diabetol Hung. 2007; 15: 313-322. [Hungarian]

[32] Wang MC, Tseng CC, Wu AB, et al. Bacterial characteristics and glycemic control in diabetic patients with Escherichia coli urinary tract infection. J Microbiol Immunol Infect. 2013; 46: 24-29.

[33] Geerlings SE, Meiland R, van Lith EC, et al. Adherence of type 1-fimbriated Escherichia coli to uroepithelial cells: more in diabetic women than in control subjects. Diabetes Care 2002; 25: 1405-1409.

[34] Malmartel A, Ghasarossian C. Bacterial resistance in urinary tract infections in patients with diabetes matched with patients without diabetes. J Diabetes Complications 2016; 30: 705-709. 
[35] Harding GK, Zhanel GG, Nicolle LE, et al. Antimicrobial treatment in diabetic women with asymptomatic bacteriuria. N Engl J Med. 2002; 347: 1576-1583.

[36] Karmaker M, Sanyal SK, Sultana M, et al. Association of bacteria in diabetic and non-diabetic foot infection - an investigation in patients from Bangladesh. J Infect Public Health 2016; 9: 267277.

[37] National Institute for Health and Care Excellence. Type 2 diabetes in adults: management. Guidance. Nice, 2019. Available from: https://www.nice.org.uk/guidance/ng28.

[38] Health care directive. [Egészségügyi szakmai irányelv.] Diabetol Hung. 2017; 25: 3-77. [Hungarian]

[39] Alberti KG, Zimmet PZ. Definition, diagnosis and classification of diabetes mellitus and its complications. Part 1: Diagnosis and classification of diabetes mellitus. Provisional report of a WHO consultation. Diabet Med. 1998; 15: 539-553.

[40] Charlson ME, Pompei P, Ales KL, et al. A new method of classifying prognostic comorbidity in longitudinal studies: development and validation. J Chronic Dis. 1987; 40: 373-383.

[41] Meerwaldt R, Graaff R, Oomen PH, et al. Simple non-invasive assessment of advanced glycation endproduct accumulation. Diabetologia 2004; 47: 1324-1330.

[42] Behrendt CA, Sigvant B, Szeberin Z, et al. International variations in amputation practice: a VASCUNET report. Eur J Vasc Endovasc Surg. 2018; 56: 391-399.

[43] Health care directive - Treatment of diabetic foot syndrome in adult (clinical picture, diagnostics, therapy, prevention. [Egészségügyi szakmai irányelv - A diabéteszes láb szindrómában szenvedố cukorbetegek ellátása felnóttkorban (klinikai kép, diagnosztika, terápia, megelőzés).] Eü Közl. 2018; 68: 547-582. [Hungarian]
[44] Murali TS, Kavitha S, Spoorthi J, et al. Characteristics of microbial drug resistance and its correlates in chronic diabetic foot ulcer infections. J Med Microbiol. 2014; 63: 1377-1385.

[45] Lye WC, Chan RK, Lee EJ, et al. Urinary tract infections in patients with diabetes mellitus. J Infect. 1992; 24: 169-174.

[46] Kline KA, Lewis AL. Gram-positive uropathogens, polymicrobial urinary tract infection, and the emerging microbiota of the urinary tract. Microbiol Spectrum 2016; 4(2): doi: $10.1128 / \mathrm{mi}-$ crobiolspec.UTI-0012-2012.

[47] López-de-Andrés A, de Miguel-Díez J, Jiménez-Trujillo I, et al. Hospitalisation with community-acquired pneumonia among patients with type 2 diabetes: an observational population-based study in Spain from 2004 to 2013. BMJ Open 2017; 7: e013097.

[48] Donnelly JP, Nair S, Griffin R, et al. Association of diabetes and insulin therapy with risk of hospitalization for infection and 28day mortality risk. Clin Infect Dis. 2017; 64: 435-442.

[49] Lipsky BA, Tabak YP, Johannes RS, et al. Skin and soft tissue infections in hospitalised patients with diabetes: Culture isolates and risk factors associated with mortality, length of stay and cost. Diabetologia 2010; 53: 914-923.

[50] Mortensen HB, Vølund A. Application of a biokinetic model for prediction and assessment of glycated haemoglobins in diabetic patients. Scand J Clin Lab Invest. 1988; 48: 595-602.

(Barkai László József dr., Budapest, Üllői út 26., 1085 e-mail: barkai.lj@gmail.com)

\section{Az Orvosi Hetilap 2019, 160, 1404. oldalán (35. szám) megjelent OH-Kvízre egy helyes megfejtés érkezett.}

A beküldő: Dr. Bíró László (Budapest).

A nyertesnek szívből gratulálunk.

Nyereményét - egy, az Akadémiai Kiadó webáruházában

kedvezményes vásárlásra jogosító kupont - e-mailen küldjük el.

A cikk a Creative Commons Attribution 4.0 International License (https://creativecommons.org/licenses/by/4.0/) feltételei szerint publikált Open Access közlemény, melynek szellemében a cikk bármilyen médiumban szabadon felhasználható, megosztható és újraközölhetö, feltéve, hogy az eredeti szerző és a közlés helye, illetve a CC License linkje és az esetlegesen végrehajtott módositások feltüntetésre kerülnek. (SID_1) 